\title{
EFFECTS OF OXYTOCIN MASSAGE ON LABOR DURATION AND UTERINE INVOLUTION AT INDEPENDENT MIDWIVERY PRACTICE SRI HASTUTI SURABAYA
}

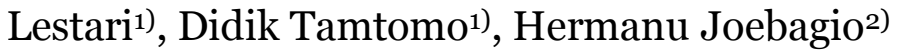 \\ 1) Masters Program in Family Medicine, Sebelas Maret University \\ 2) Graduate Program in Education, Sebelas Maret University
}

\begin{abstract}
BACKGROUND: Prolonged labor may cause poor infant clinical condition. Lengthening uterine involution may cause postpartum hemorrhage. Oxytocin is a hormone secreted by the neurons of the hypothalamus and stored in the posterior pituitary in mammals. Theoretically, oxytocin stimulates contraction of uterine smooth muscle by increasing the sodium permeability of uterine myofibrils. High estrogen concentrations lower the threshold for uterine response to oxytocin. Uterine response to oxytocin increases with the duration of pregnancy. This study aimed to determine effect of oxytocin massage on labor duration and uterine involution.

SUBJECT AND METHODS: This was an experimental study, using post test only design with a control group. It was conducted at Independent Midwivery Practice (BPM) Sri Hastutik, Surabaya, East Java. A sample of 32 pregnant mothers was monitored during the delivery and post partum processes. The dependent variables were phase I labor duration and uterine involution. The independent variable was oxytocin massage. The data was analyzed by McNemar test.

RESULTS: Pregnant mothers who received intra-partum oxytocin massage were 6.60 times more likely to have rapid labor than those who did not receive oxytocin massage $(\mathrm{OR}=6.60 ; 95 \% \mathrm{CI}=1.40$ to 31.05 ; $\mathrm{p}=0.013)$. Pregnant mothers who received intra-partum oxytocin massage were 9.53 times more likely to have rapid uterine involution than those who did not receive oxytocin massage $(\mathrm{OR}=9.53 ; 95 \% \mathrm{CI}=1.85$ to 49.20 ; $\mathrm{p}=0.004)$.
\end{abstract}

CONCLUSION: Oxytocin massage is effective to shorten labor duration and uterine involution.

Keywords: oxytocin massage, phase I labor duration, uterine involution 